Annals of Warsaw University of Life Sciences - SGGW

Land Reclamation No 44 (2), 2012: 133-142

(Ann. Warsaw Univ. of Life Sci. - SGGW, Land Reclam. 44 (2), 2012)

\title{
Determination of the coefficient of consolidation in soft organic soils using ACONS
}

\author{
EDYTA MALINOWSKA \\ Department of Geotechnical Engineering, Warsaw University of Life Sciences - SGGW
}

\begin{abstract}
Determination of the coefficient of consolidation in soft organic soils using ACONS. To determine the coefficient of consolidation using oedometer laboratory tests usually two common methods are used, Casagrande and Taylor. In the paper, the ACONS apparatus and ClispStudio program is characterized. The methodology and the test results of determination coefficient of consolidation in soft organic soils are presented. In the paper, the laboratory test results obtained from Automatic CONsolidation System are analyzed and the relationships between coefficient of consolidation, void ratio, and vertical stress are also presented.
\end{abstract}

Key words: coefficient of consolidation $\left(c_{v}\right)$, soft organic soils, ACONS.

\section{INTRODUCTION}

To determinate the coefficient of consolidation using odeometer apparatus usually two common methods, leaning on Terzaghy theory, are used; Casagrande and Taylor (Head 1982). Therefore the exactly time of primary and secondary consolidation or degree of the consolidation should be known (Mesri and Godlewski 1977). Sometimes, it is impossible in soft organic soils.

The observation of deformation performance in field and laboratory investigations indicated that the consolidation process consist of two stages: primary settlement (immediate and consolidation), and secondary and tertiary settle- ment (creep) (Szymański and Sas 2001). The results of laboratory tests indicate that the parameters describing secondary compression depend on the effective stress level. Conventionally, the second phase of the settlements is regarded as being approximately linear in log time and is described as secondary settlements. In the long-term tests there is sometimes an upwards curvature of the log time-settlement curve in the secondary compression phase-creep. This phenomenon is called tertiary compression. Secondary and tertiary settlement is the result of creep of soil skeleton under the effective stress. It depends on rheological properties of soil and significantly depends on time (Sas et al. 2010).

The consolidation coefficient $\left(c_{v}\right)$ is one of the mechanical parameters that should be obtained to estimate the value and the rate of strain of the soft organic subsoil under different loading $\left(\sigma_{v}{ }^{\prime}\right)$. To determinate the coefficient of consolidation the value of the total settlement in time and the degree of consolidation should be known.

To obtain the consolidation coefficient in soft organic soils it is necessary to find the exact point of the end of consolidation settlement. Without knowing the time of $100 \%$ dissipation of water pore pressure it is difficult even in the automatic oedometer. In soft organic soils the 
time between consolidation settlement and tertiary settlement (creep) can be undetected. That's why it is difficult to find the $t_{50}$ for $U=50 \%$ of consolidation for Casagrande method. The Taylor method is based on the changes of soil sample high in square time (Lambe and Whitman 1969; Mesri and Godlewski 1977; Head 1982).

\section{MATERIALS AND METHODS}

The ACONS is the shortcut of Automatic CONsolidation System. The system consist of: 1 - computer with ClispStudio program, 2 - miniscanner for registration, 3 - three automatic oedometers (display on photo below).

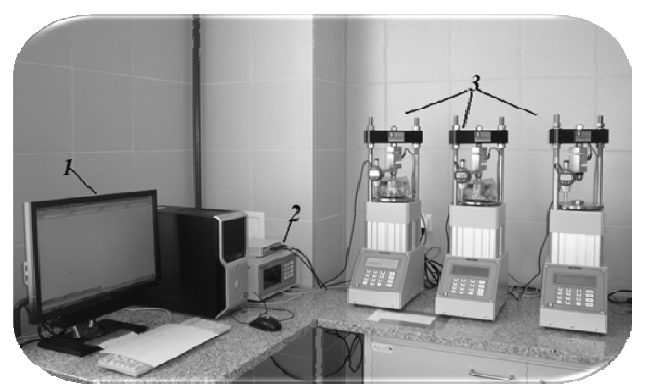

The main advantage of this system is the simplicity and automatization of the laboratory testing. On the every stage of the test it is possible to check and change the test conditions.

The set with ACONS apparatus and ClispStudio Program allows programming the swelling and consolidation tests. Different values of loading can be used with different conditions of start, stop and measurement criteria. The loading is pneumatic. With these three oedometers, three different samples in three diameters: 50, 75 and $100 \mathrm{~mm}$, can be tested in the same time. The samples can be as well NNS, as NS.

In the ClispStudio program it is possible to set initial physical parameters and loading value. The program is able to read record and plot the results during the test (Fig. 1).

The program records the test results and the main characteristics can be analyzed during the test (Fig. 2).

The coefficient of consolidation in ACONS can be also calculated by the Casagrande or Taylor method, but the value of the coefficient of consolidation

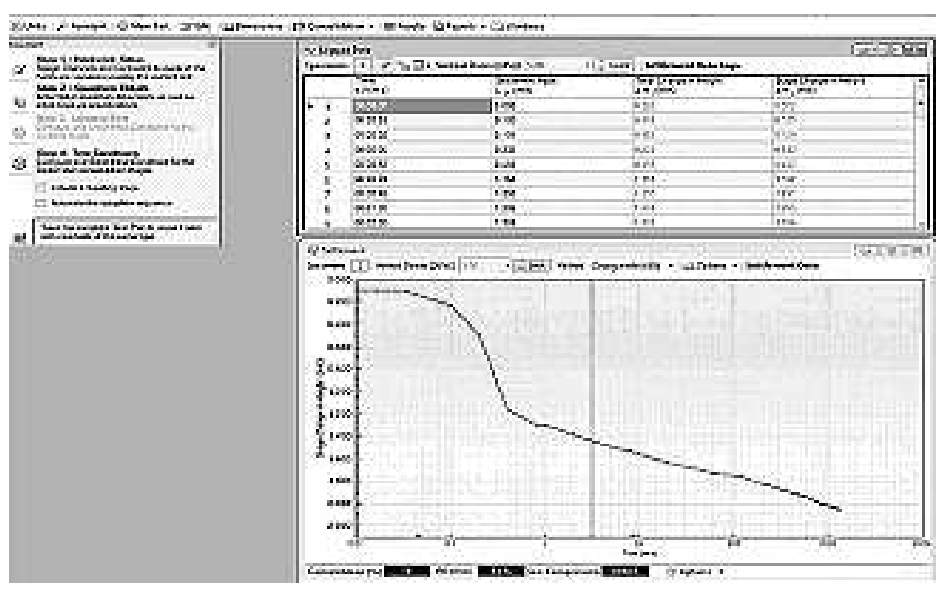

FIGURE 1. Sample of ACONS test recording made by ClispStudio 

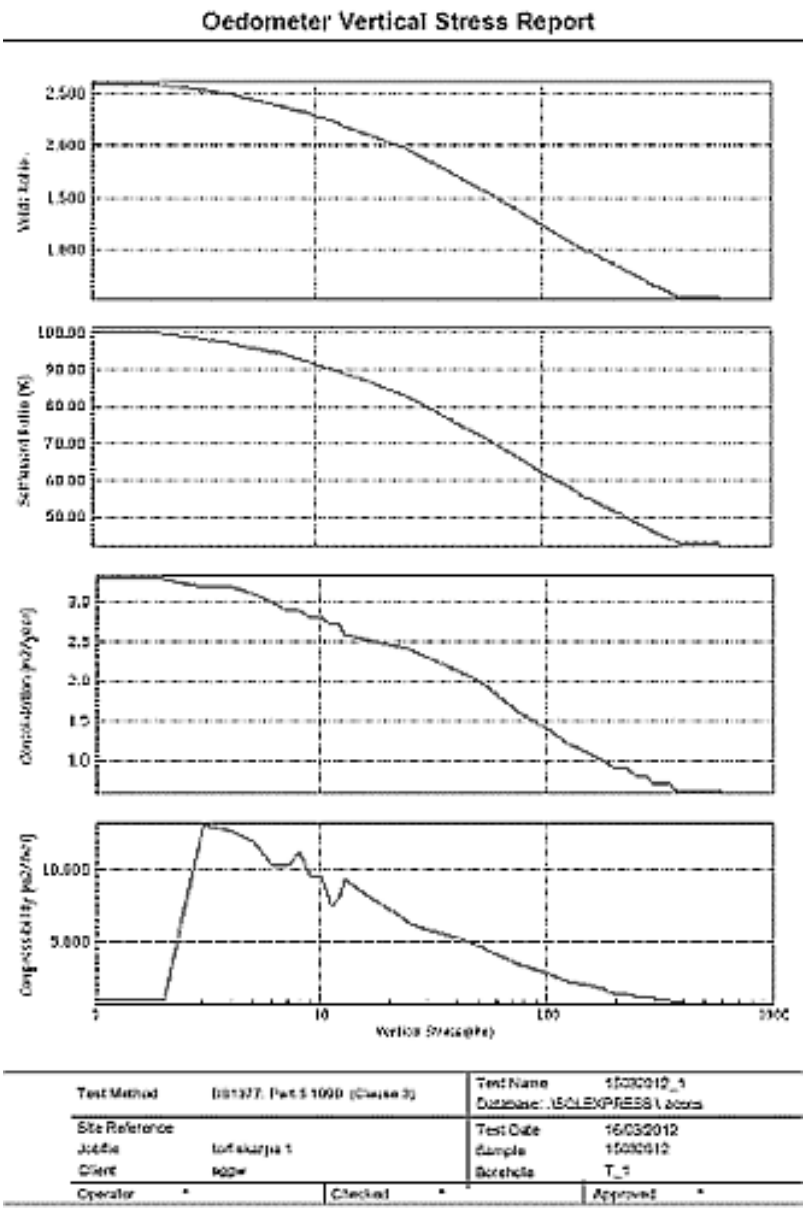

FIGURE 2. Sample of ACONS test results report made by ClispStudio

obtained from ClispStudio Program is not reliable. Only the curves plotted by the program can be used as the base to determine the coefficient. The curve plotted in the Casagrande method is in log time (Fig. 3) and the curve plotted by Taylor method is in square time (Fig. 4).

\section{RESULT ADD DISCCUSSION}

\section{The test results of coefficient of consolidation}

The laboratory tests are performed on soft organic NNS samples, taken from the Campus SGGW test site (Table 1). 


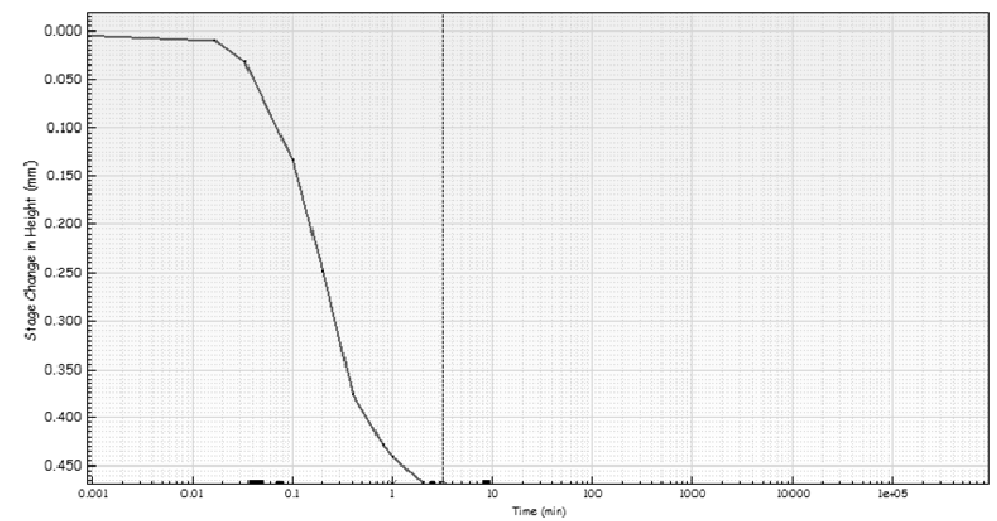

FIGURE 3. Sample of ACONS test results plot for Casagrande method

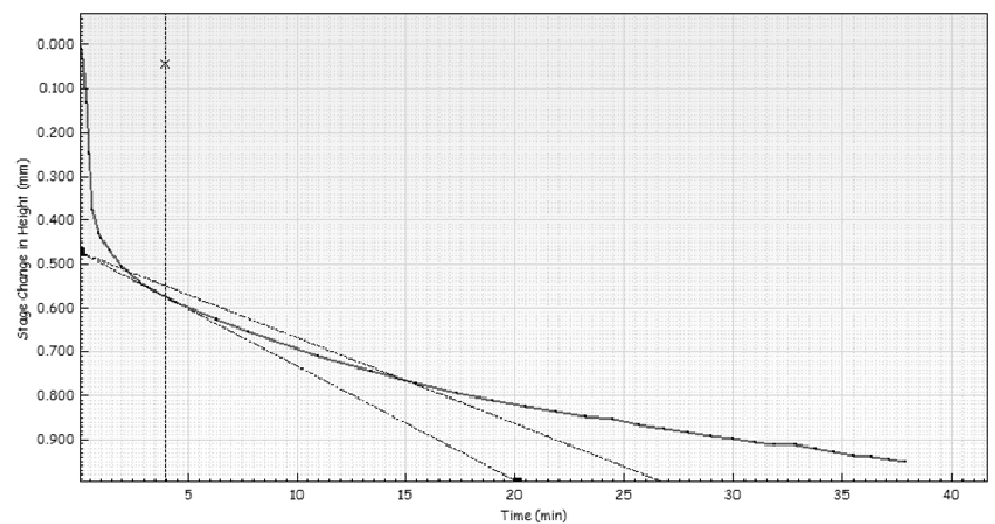

FIGURE 4. Sample of ACONS test results plot for Taylor method

TABLE 1. Physical properties of organic soils at tested site

\begin{tabular}{|l|l|}
\hline Properties & Peat \\
\hline Water content [\%] & 400 \\
Density of solid particles $\rho_{s}\left[\mathrm{t} / \mathrm{m}^{3}\right]$ & $>1.58$ \\
Bulk density $\rho\left[\mathrm{t} / \mathrm{m}^{3}\right]$ & 1.22 \\
Plastic limit $w_{p}[\%]$ & 136 \\
Liquid limit $w_{L}[\%]$ & 255 \\
Plasticity index $I_{p}[\%]$ & 118 \\
Liquidity index $I_{L}[\%]$ & 2.23 \\
Organic matter content $I_{O M}[\%]$ & 75 \\
Degree of humification $R[\%]$ & 65 \\
\hline
\end{tabular}

The automatic consolidation system was used to obtain the stress-strain characteristics in soft organic soils in different range of loading, from 1 to $40 \mathrm{kPa}$. The oedometer tests consist of swelling and consolidation process.

The initial conditions are as follows:

- initial high $[\mathrm{mm}]-20$,

- initial diameter [mm] - 75,

- initial weight [gr] - 109.5,

- saturation [\%] - 100,

- applied stress $[\mathrm{kPa}]-1 \div 40$.

The measured and calculated parameters are as follows: 
- time [h:m:s],

- stage change in high [mm],

- void ratio $e[-]$,

- coefficient of consolidation $c_{v}\left[\mathrm{~m}^{2} / \mathrm{s}\right]$. The consolidation curve is presented in Figure 5. The value of the strain in time for vertical stress equal $10 \mathrm{kPa}$ is presented in Figure 6.

To determinate the coefficient of consolidation in soft organic soils the Casagrande and Taylor method is used (Figs 7 and 8).

The comparisons between values of coefficient of consolidation determinat- ed by the Casagrande and Taylor method are presented in Table 2.

\section{The ACONS test results analysis}

The soft organic soils are very compressible and anisotropic. Because of that, to complete the characterization of the strain parameters in soft organic soils, it is necessary to analyze the test results in the relationship between strain and void ratio in time (Fig. 9).

Analyzing the relationship between strain and void ratio in time it is possible

\section{Time [s]}

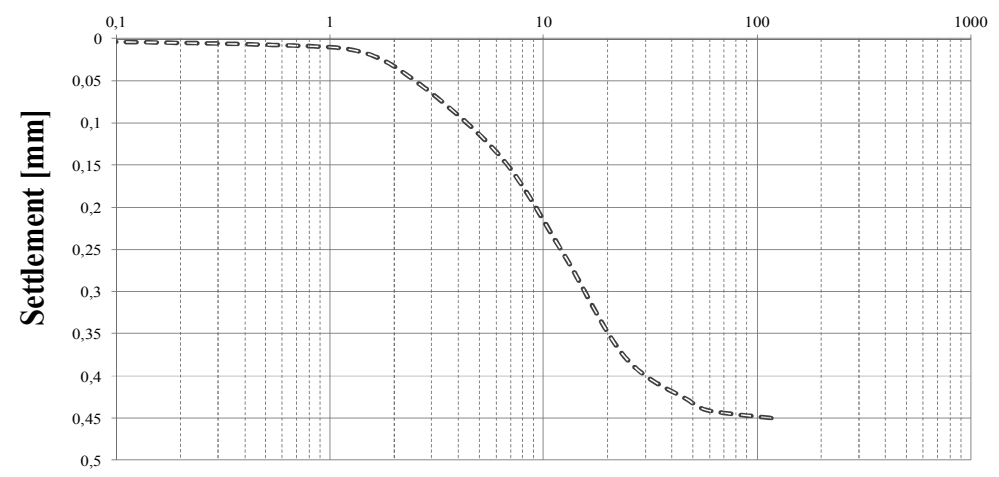

FIGURE 5. The consolidation curie for vertical stress equal $10 \mathrm{kPa}$

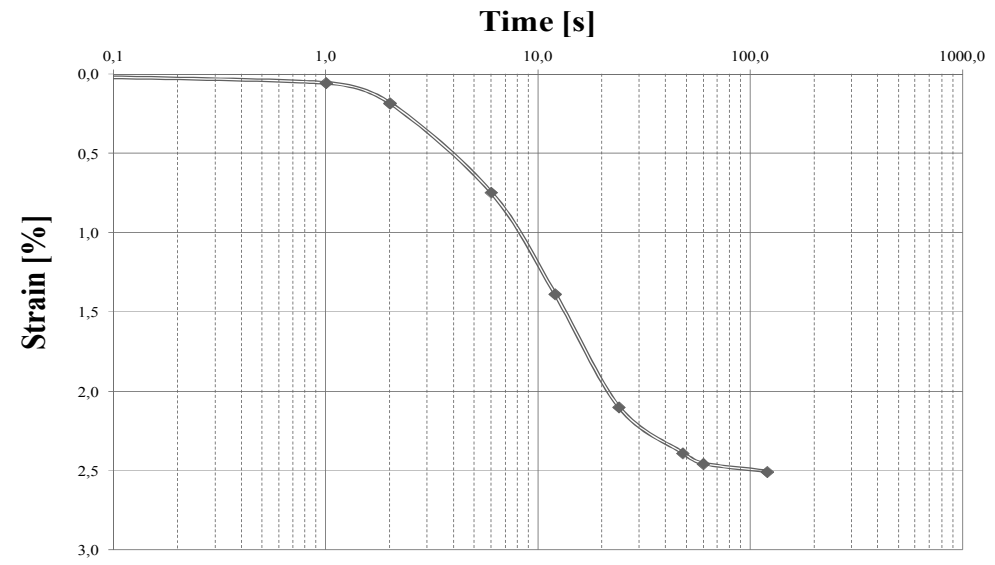

FIGURE 6. The value of the strain in time for vertical stress equal $10 \mathrm{kPa}$ 


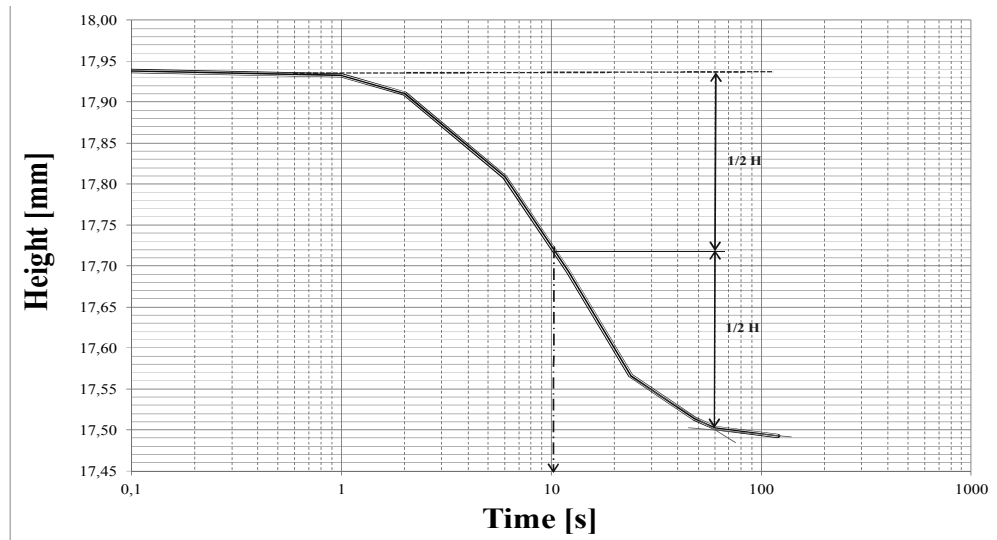

FIGURE 7. Determination of coefficient of consolidation by the Casagrande method for vertical stress equal $10 \mathrm{kPa}$

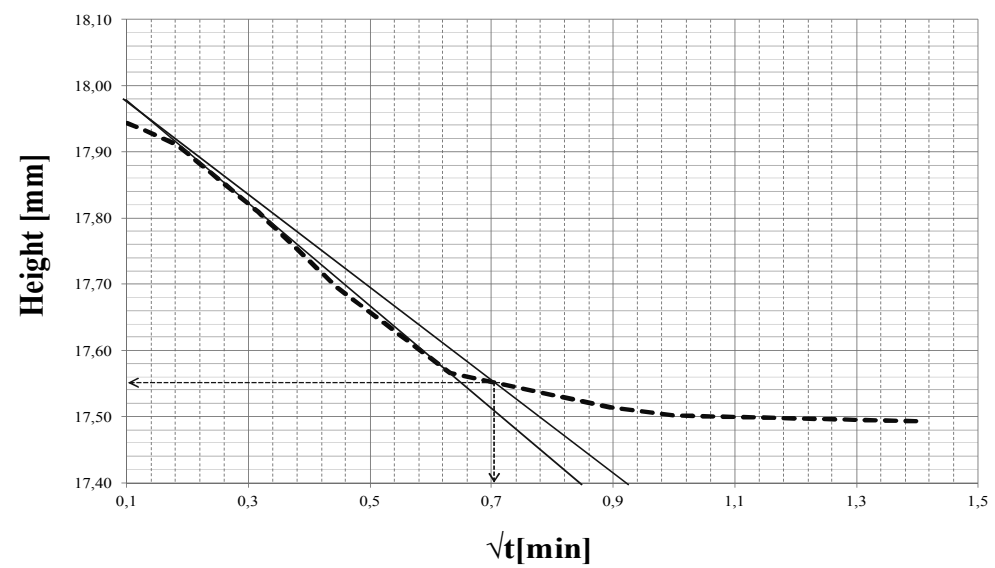

FIGURE 8. Determination of coefficient of consolidation by the Taylor method for vertical stress equal $10 \mathrm{kPa}$

TABLE 2. The comparison between the coefficient of consolidation determinate by the Casagrande and Taylor method

\begin{tabular}{|l|c|c|c|}
\hline$\sigma_{v}{ }^{\prime}[\mathrm{kPa}]$ & $e[-]$ & $\begin{array}{c}C_{v}\left[\mathrm{~m}^{2} / \mathrm{s}\right] \\
\text { Casagrande method }\end{array}$ & $\begin{array}{c}C_{v}\left[\mathrm{~m}^{2} / \mathrm{s}\right] \\
\text { Taylor method }\end{array}$ \\
\hline 5.0 & 6.05 & $6.15 \cdot 10^{-6}$ & $8.30 \cdot 10^{-6}$ \\
\hline 10.0 & 5.60 & $6.01 \cdot 10^{-6}$ & $7.69 \cdot 10^{-6}$ \\
\hline 15.0 & 5.35 & $5.94 \cdot 10^{-6}$ & $7.54 \cdot 10^{-6}$ \\
\hline 20.0 & 5.10 & $5.20 \cdot 10^{-6}$ & $3.71 \cdot 10^{-6}$ \\
\hline 25.0 & 4.95 & $4.96 \cdot 10^{-6}$ & $3.51 \cdot 10^{-6}$ \\
\hline 30.0 & 4.80 & $4.89 \cdot 10^{-6}$ & $3.30 \cdot 10^{-6}$ \\
\hline 35.0 & 4.60 & $4.61 \cdot 10^{-6}$ & $3.05 \cdot 10^{-6}$ \\
\hline 40.0 & 4.40 & $4.47 \cdot 10^{-6}$ & $3.00 \cdot 10^{-6}$ \\
\hline
\end{tabular}




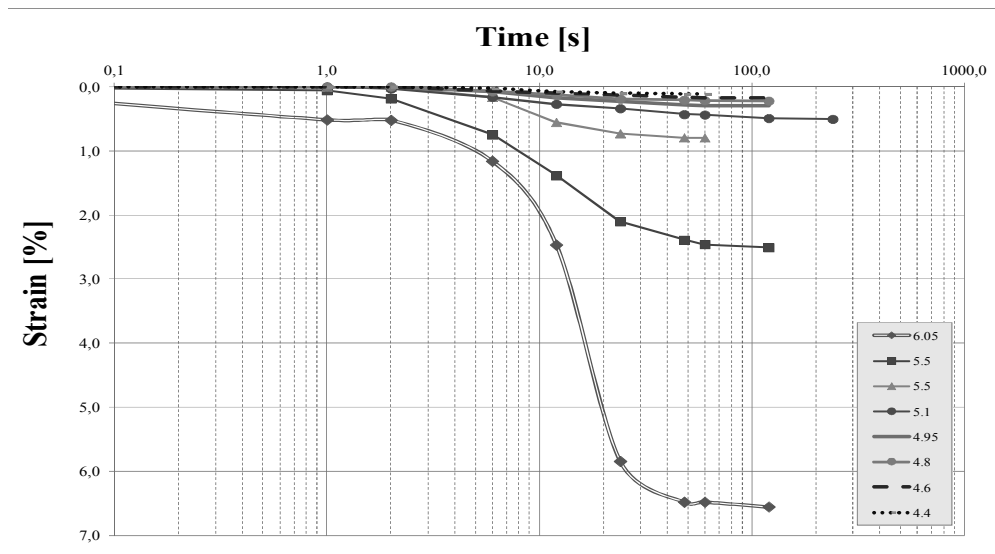

FIGURE 9. The value of strain in time for different void ratio

to propose a function that characterized characterized dependence between coefthis dependence (Fig. 10):

$\varepsilon=2.0 \times 10^{-6} \times e^{6.5} \times t^{0.25}[\%]$

(1) and void ratio changes (Fig. 12):

where: $\varepsilon-$ strain [\%], $e-$ void ratio [-], $\quad c_{v}=2.0 \times 0^{-6} \times e^{1.1} \times \sigma^{,-0.35}\left[\mathrm{~m}^{2} / \mathrm{s}\right]$ $t$ - time [s].

where:

The Figure 11 point out the relationship between coefficient of consolidation in soft organic soils and void ratio.

And also, analyzing this relationship $c_{v}$ - vertical coefficient of consolidation $\left[\mathrm{m}^{2} / \mathrm{s}\right]$

$e-$ void ratio $[-]$, $\sigma^{\prime}-$ vertical stress $[\mathrm{kPa}]$. it is possible to propose a function that

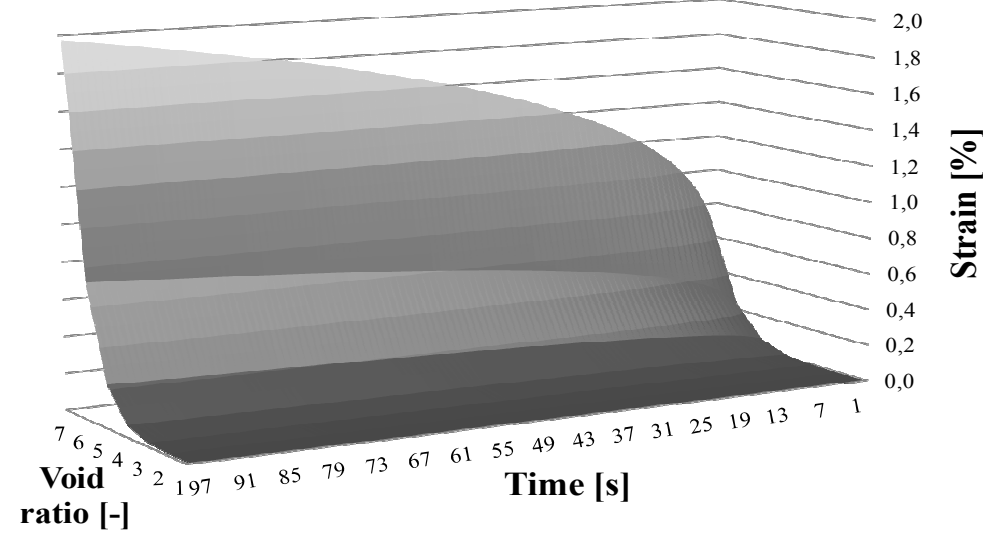

FIGURE 10. The relationship between strain and void ratio in time 


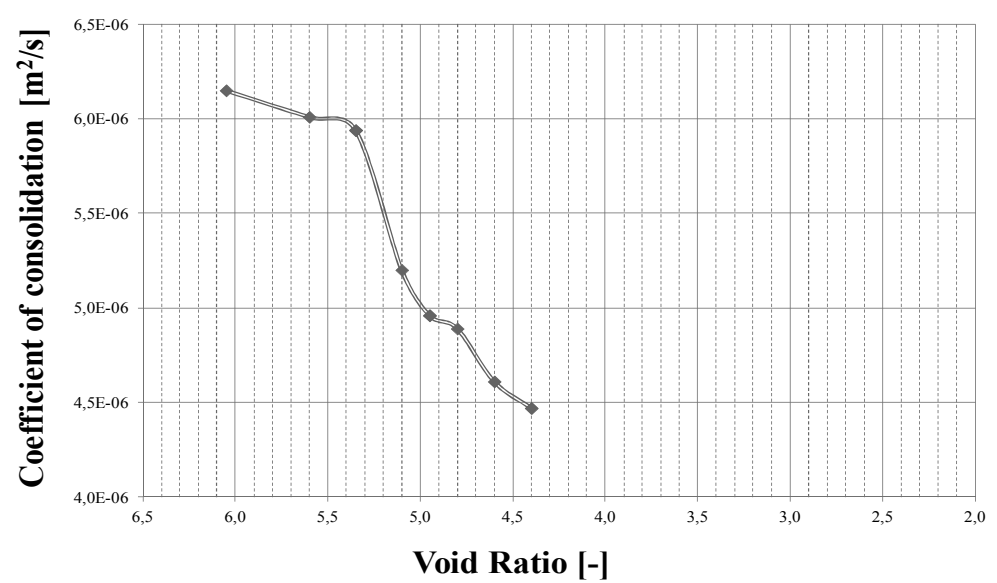

FIGURE 11. Change of coefficient of consolidation in void ratio

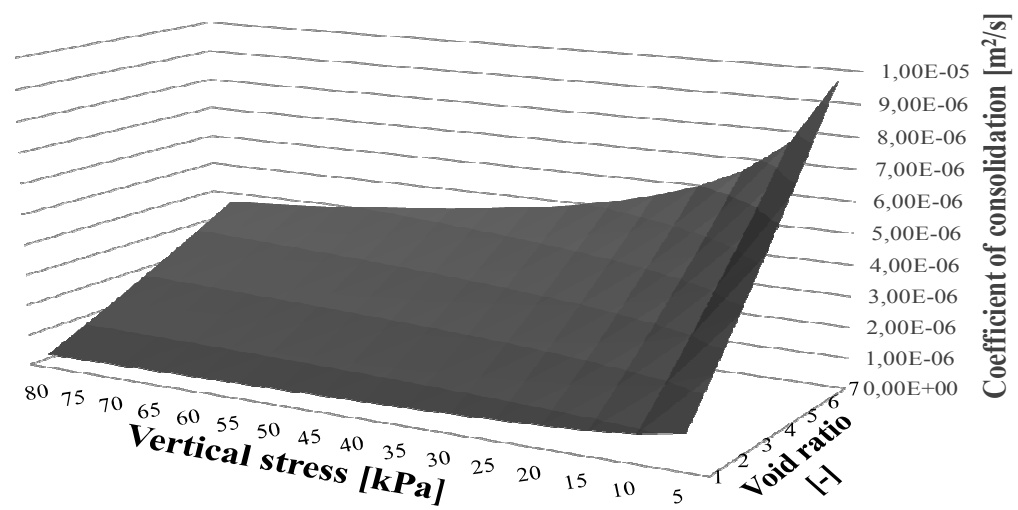

FIGURE 12. The relationship between coefficient of consolidation, void ratio and stress

\section{CONCLUSIONS}

The ACONS set allows to cut the time of the research that is a consequent's of pneumatic loading. The test type can be selected as swelling or consolidation with different border conditions. Three different tests on three different soils samples in three different dimensions can be tested at the same time. The ClispStu- dio program allows reading, writing and plotting the test results during the test.

To obtain coefficient of consolidation is soft organic soils it is important and extremely different to find the point of the end of consolidation stain and the beginning of tertiary stain that is very significant in this very compressibility and anisotropic soils. The Figure 13 point out the change of settlement in soft organic 


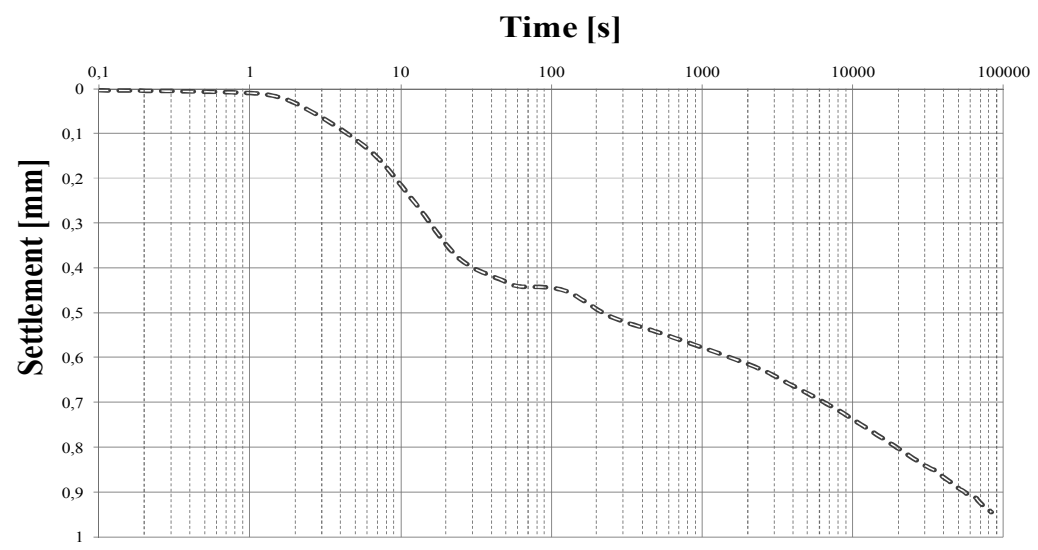

FIGURE 13. Change of settlement in long time for $10 \mathrm{kPa}$ vertical stress

soil under $10 \mathrm{kPa}$ stress, in long time period including creep process.

The coefficient of consolidation in soft organic soils should be obtained with the knowledge of the water pore pressure dissipation that gives the possibility of better identification of stressstain characteristics.

The value of coefficient of consolidation in soft organic soils changes with the void ratio from $6.15 \cdot 10^{-6}\left[\mathrm{~m}^{2} / \mathrm{s}\right]$ to $4.47 \cdot 10^{-6}\left[\mathrm{~m}^{2} / \mathrm{s}\right]$ for Casagrande method that will be further considered. The comparison between values of the coefficient of consolidation obtained from the Casagrande method and Taylor method point out that the Casagrande method is more correct.

The dependence between coefficient of consolidation in soft organic soils in different vertical loading value and void ratio can be written as follows:

$c_{v}=2.0 \times 10^{-6} \times \mathrm{e}^{1.1} \times \sigma^{,-0.35}\left[\mathrm{~m}^{2} / \mathrm{s}\right]$

where:

$c_{v}$ - vertical coefficient of consolidation $\left[\mathrm{m}^{2} / \mathrm{s}\right]$, $e-$ void ratio [-],

$\sigma^{\prime}-$ vertical stress $[\mathrm{kPa}]$.

\section{REFERENCES}

HEAD K.H. 1982: Manual of Soil Laboratory Testing, Vol. 3.

LAMBE T.W., WHITMAN R.V. 1969: Soil Mechanics. Wiley Book Company.

MESRI G., GODLEWSKI P.M. 1977: Timeand stress-compressibility interrelationship. Journal of Geotechnical Engineering, ASCE 103(5), 417-430.

SAS W., SZYMAŃSKI A., MALINOWSKA E., NIESIOŁOWSKA A. 2010: Physical and mechanical properties of problematic soils in Poland. Proceedings of the XIVth Danube-European Conference on Geotechnical Engineering. Published by Slovak University of Technology, Faculty of Civil Engineering, Bratislava, Session 1 "Ground characterization and new development in soil mechanics", 2010.

SZYMANSKI A., SAS W. 2001: Deformation characteristics of organic soils. Ann. Warsaw Agri. Univ., Land Reclam. 32, 117-126. 


\section{E. Malinowska}

Streszczenie: Wyznaczanie wspótczynnika konsolidacji w stabonośnych gruntach organicznych $z$ wykorzystaniem zestawu ACONS. W celu wyznaczenia współczynnika konsolidacji w słabonośnych gruntach organicznych w laboratoryjnych badaniach edometrycznych zwykle stosowane są dwie podstawowe metody, Casagrande'a i Taylora. W artykule przedstawiono ACONS (zestaw automatycznych edometrów) wraz z oprogramowaniem ClispStudio. Podano charakterystykę zestawu i metodykę wyznaczania współczynnika konsolidacji w słabonośnych gruntach organicznych. $\mathrm{W}$ artykule zostały przedstawione i przeanalizowane wyniki badań uzyskane z ACONS. Zaproponowano także funkcję opisującą zależność współczynnika konsolidacji od wskaźnika porowatości i pionowego naprężenia.
Słowa kluczowe: współczynnik konsolidacji $\left(c_{v}\right)$, słabonośne grunty organiczne, ACONS.

MS. received in November 2012

\section{Author's address:}

Edyta Malinowska

Katedra Geoinżynierii

Wydział Budownictwa i Inżynierii i Środowiska SGGW

ul. Nowoursynowska 159, 02-787 Warszawa

Poland

e-mail: edyta_malinowska@sggw.pl 